European Journal of Science and Mathematics Education

Vol. 2, No. 3, 2014, 155-166

\title{
Development of the structured problem posing skills and using metaphoric perceptions
}

\author{
Elif Esra Arikan ${ }^{1}$ and Hasan Unal ${ }^{2}$ \\ ${ }^{1}$ Department of Mathematics, PhD Candidate, Yildiz Technical University, Turkey. \\ 2 Department of Elementary Mathematics Education, Yildiz Technical University, Turkey. \\ For correspondence: arikanee@gmail.com
}

\begin{abstract}
:
The purpose of this study was to introduce problem posing activity to third grade students who have never met before.This study was also exploredstudents' metaphorical images on problem posing process. Participants were from Public school in Marmara Region in Turkey. Data was analyzed both qualitatively (content analysis for difficulty and limitedness of pose problems and metaphorical imagination) and quantitatively (non-parametric Wilcoxon Sign Test). Since experimental and control group were not used in the study, this study was nonexperimental study. The participants were mingled with problemsfor warming up to generate a problem by themselves.After that they were offered threesemi-structured probelmatics situations. Students were asked create a systematic structure to given problematic situationsComparisons were made by means of pre-test and post-test. The results of this study revealed that the students were successful in structured type considerably. Further, students' insight on problem posing was identified by metaphors.
\end{abstract}

Keywords: Problem posing program, third grade students, using metaphor.

\section{Introduction}

Problem posing has been attracted many researchers in the field of mathematics education.It was emphasized that generating a problem is much more important than solving it (Einstein\&Infeld, 1938). Since then, problem posing is a subject of debate in the world of education. Many studies have examinedthe effect of problem posing ability and how to improve this ability. Researchers' emphasis was placed on that problem posing ability can be improved as generating a new problem from a given situation and reformulation of given a problem (Duncker, 1945; Leung, 1993;Silver, Mamana\&Downs, 1993). Problem posing is made up of three types; free type, semi-structured type and structured type.

Free type: pose a problem which is particularly difficult. For this type, it can be given a sentence to students and asked students generate a problem by using the information in some way.

Semi-structured type: pose a problem which is given by equation, photograph, figure or table.

Structured problem posing situations: pose a problem which is reconstruction from well-built problem or solution of problem. (Stoyanova \& Ellerton, 1996).

It was stated that problem posing situations as following below:

"Free Type: make up a simple or difficult problem, make up a problem you like, generate a problem for mathematics test or competitions.

Semi-structured type: Students are given an open situation and are invited to explore it using knowledge, skills, concepts and relationships from their previous mathematical experiences. 
Structured type: Any mathematical problem consists of known data (given) and unknown (required). The teacher can simply change the known and pose a new problem, or keep the data and change the required" (Abu-Elwan, 2002: p.57).

In the another study, it was presented these categories like that

Free type: "There are 10 girls and 10 boys standing in a line". Generate as many as problems by using the information in some way.

Semi-structured type: generate many problems by using in the following figure.

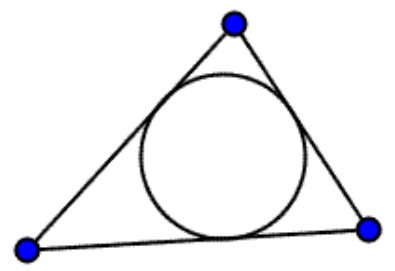

Structured type: "Last night, there was a party at your cousin's house and the doorbell rang 10 times. The first time the doorbell rang only one guest arrived. Each time the doorbell rang, three more guests arrived than had arrived on the previous ring"

a) How many guests will enter on the tenth ring? Explain how you found your answer.

b) Ask as many questions as you can that are in some way related to this problem ( Harpen\&Presmeg, 2013:p. 119).

Namely, a problem is posed from current problem.

"what-if-not strategy" is an important strategy of problem posing activity (Brown\&Walter, 1990). In this strategy, conditions are given problem are changed. To implement this strategy, some questions are asked by one's own like that "What if I look at the converse?" and "what if it were not so?. It was remarked that "Problem posing is deeply embedded in the activity of problem solving in two very different ways First of all[...] what isthis problem really asking, saying, or demanding? What if I shift my focus from what seems to be an obvious component of this problem to a part that seems remote? Second, it is frequently the case after we have supposedly solved a problem, we do not fully understand the significance of what we have done, unless we begin to generate and try to analyze a completely new set of problems"( Brown\&Walter, 2005: 2-3).

Therefore, this strategy is classified as structured problem posing type (Lavy\&Shriki, 2007).

Problem posing could materialize as prior to problem solving, during the problem solving or after problem solving (Silver, 1994). Researchers can examine the interrelationship between problem solving and problem posing (Stoyanova\&Ellerton, 1996). For example, a comparative analysis between eight high ability students and eight low-ability students in problem solving was made. As a result, high ability students were more successful for generating complex problems (Ellerton, 1986).

Similarly, a correlation was found that students' problem solving ability was relatedto their problem posing performance (Silver\&Cai, 1996). Students have had high performance in problem solving posed more complex mathematical problems.

\section{The Power of Problem Posing}

When students pose a mathematical problem, they have to considerits solution whether it is solvableor not (Cai \& Hwang, 2002). This is the indicator of relation between problem posing and problem solving. Hence students' problem solving ability can be fostered during problem posing activity. By looking at the principles and standards of NCTM (National Council of Teachers of Mathematics, 2000), problem posing is an important component of problem solving, recognizing it as an indication of mathematical disposition" (Armstrong, 2013). 
Problem posing could be viewed as challenging activity to acquire a deeper mathematical thinking. Real world provides us with a chance to generate many mathematical problems. Problem posing has the potential to trigger creativity (Georgiev and Nedyalkova, 2011). Today' societies are in need of more creative and critical tkinking individuals. On top of Turkey this situation applies to South Africa. The Norms and Standards for Educators (SA, 27/ 1996) elaborate that teachers must design an environment such that their students can think critically and creatively during the learning process (Meintijes\&Grosser, 2010). Industrialized countries such as Australia, China and US accept problem posing to develop the creativity for students in mathematics education. Jordan (2007) explained in the following words: “(...) African communitieshad come to realize that it was only by acquiring these same skills and knowledge that Africans could hope to compete on an equal basis with western nations"

During the problem posing activity as a teaching strategy, students may feel less pressure to find the right answer and may believe in themselves to present their mathematical thinking abilities (Baxter, 2005). It was included this topic in "the art of problem posing" book that "There is good reason to believe that problem generation might be a critical ingredient in confronting math anxiety because the posing of problem for asking a question is potentially less threatening than answering them. The reason is in part a logical one. That is, when you ask a question, the responses "right" or "wrong" are inappropriate, although that category is paramount for answer to questions" (Brown\&Walter, 2005). Hence, students may be motivated to investigate mathematical understanding without anxiety (Buerk, 1982). In another study, it was emphasized that "Motivation is another factor that may play a significant role in the experience of mathematics anxiety" (Hlalele, 2012: 270).

When students pose a problem, they use their perception and interpretation of concrete situation (Bonotto, 2010). In the light of all the studies mentioned above, problem posing is accepted as a cognitive mechanism for creative thought (Pelczer\& Rodriguez, 2010).

Based on previous studies show that the on problem posing, it is possible to say that problem posing plays an important role on improvement of problem solving. Problem posing develops creative thinking skills (Mestre, 2002). Furthermore, so far as problem posing is concerned, students have more creative mathematical thinking (Whitin, 2004; Cai, Singer, Ellerton and Leung, 2011).

\section{Using Metaphor for Determination of Attitude towards the Problem Posing}

"What we perceive, how we get around in the world, and how we relate to other people are being structured with our concept"(Lakoff\&Johnson, 1980, p.124). It was emphasized that "Metaphor is employed when one wants to explore and understand something esoteric, abstract, novel, or highly speculative" (Yob, 2003: 134).

Metaphor entails reflecting one kind of thing in terms of another (Lakoff\&Johnson, 1980). For this reason, metaphor is a powerful cognitive tool for educators. Metaphor is for describing an unknown by means of a known. The major function of metaphor isdescribed as the the fact that it is a mechanism whichhelps to understand abstract concepts and reason between from one to the other one, it is used for editing conceptual upheaval, it is a map between target and domain source and it is based on the daily experience and knowledge (Lakoff, 1992)."For myself, as well as in facilitating reflective practice for others, I have found that the exploration and articulation of one's use of metaphor is an important element in the process of demystifying the passage of personal 'intuitive' knowledge into professional practice. In my experience, metaphor is a vehicle uniquely well-designed to negotiate and make sense of the creative space between what is personal and what becomes public (Hunt, 2006: 317). 
The example of expression of "Teacher is as a compass" refers teachers' analogous definition. In other words, it is interpreted that teacher is aimer and conductor like a compass. In the study, metaphor was used for perception of students' over the problem posing.

In this study, the students completed the semi-structured sentence of "Problem posing is like....because...." to obtain data about their perceptions of problem posing after the sessions.

\section{Method}

\section{Problem Posing Program}

The present study was aimed to explorehow to develop third grade students' structured problem posing abilities. Accordingly, three semi-structured problem situations were used. This study scope of two semesters consisting of winter semesterand spring semesters. Twenty lesson-hours were spent for both fostering students' problem posing ability and carrying out the process itself. In this process, a generated problem which had been admired by all students in the class was written on board from time to time. The class teacher consistently informed her students to pay attention to consistent number, perfect knowledge, grammar and chain of reasoning.

Hence, students' awareness was developed for generating a problem by interaction with their peers.

Following the process after pre-test in winter semester, the program comprising 40 minutes sessions per week (total 20 week) was implemented and post-test was carried out. Throughout each session, because students werein third grade, the class teacher took an active role to enable validity and reliability of the study in guiding the process. This process consisted of semi-structured problem posing according to respectively two operations (SSPP-O), semi-structured problem posing according to figure (SSPP-F), semi-structured problem posing and according to table (SSPP-T).

In the final part of the study, metaphor used to ascertain perception of students about problem posing. Owing to the fact that the number of students is only 40, they were wanted to create a metaphor such that two categories in positive or negative way about problem posing. Descriptive statistics for percents and qualitative analysis is used for metaphoric perceptions and teacher views

\section{Participants}

The study was conducted with 40 third grade students studying at elementary schools located in Istanbul. When the participants were selected, it was noticed to the students to be successful. Therefore, convenient sampling was applied for successful class level at school.

\section{Data Collection and Analysis}

The present study was non-experimental comparative study to determine the differences between before and after applying the problem posing program. Also, mixed approach research method was implemented for consistency of the results of the study. First of all, quantitative results were analyzed. Subsequently, researchers tried to get qualitative results by students' perceptions of problem posing activity.Students were coded as $S_{1}, S_{2}, S_{3}, \ldots, S_{40}$. Frequency results of pre-test and post-test were given for structured problem posing situation that is "“Erol has read 187 pages of his book. Nurdan has read more than 28 pages of Erol's pages. How many pages have Erol and Nurdan read?" in Table 2, the differences between the pre-tests and post-tests were given in Table 3 and difficulties and limitations were given in Table 4.

Data were subjected to analysis of nonparametric Wilcoxon Sign Test whether there were considerable difference between pre-test and post-test. Also, content analysis was used to determine limitedness and difficulty that challenges faced by students in problem posing. 
Metaphors was analyzed as frequency and percent distribution according to gender and response in Table 5 and Table 6.The participants of the study were 40 of third grade students. They mingled with three semi-structured types according to operations, figure and table and after that they were asked to pose a structured problem posing situation. For scoring posed problem was that

Problem

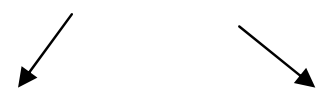

writing a sentence of question (1 point) Else (0 point)

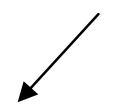

The problem to be solved ( 2 points)

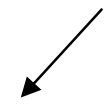

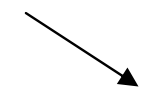

Else (0 point)

appropriate to given (2 points) Else (0 point)

Providing that student posed problem properly, his/her performance was evaluated with 5 points. Additionally, structured interviews were carried out with class teacher and it was presented in Table 7.

\section{Purpose of This Study}

1. Identifyingwhetherproblem posing ability could be improved by using semi-structured problem type

2. Determining students' perception about problem posing by generating metaphorical expression,

3. Stating the class teacher's thoughts about problem posing activity.

\section{Findings}

\section{Warming up to problem posing activity}

First of all, students were presented without any constraint on making their mathematical experience by using their imagination. The students were asked what they point to take into consideration in problem posing. It was observed that they noticed relationship between problem posing and problem solving.

Thereafter, one by one student got on the board in order to pose a problem. This session passed with informal discussions concerning the deficiency of posed problem. Considerations were classified as consistent number and related with real life.

Moreover, it was requested from the students to think about posing complex problems by using large numbers.

Analyzing of the posed problems was including some problems which was irrelevant to real life and some problems was generated with myriad of questions concerning a difficult problem. Some of this problems was presented in the following samples;

$S_{3}:$ "My younger sister is 3 years old, my older sister is 4 years old and I am 2 years old. How old are we?"(logic error) 
S19:"Nurdan sewed 3 socks and Elif sewed her 6 times more than her socks. Later, Elif took home 3 socks. Then, how many socks did Elif sew?"(sewed socks dont decrease, remainder may asked)

$S_{21}$ : "I have 5 apples. I gave 4 times to my sister. How many apple do I have?" (logic error)

$\mathrm{S}_{29}$ : "Ahmet has got 28 marbles. His brother has got $\frac{4}{5}$ of Ahmet's marbles. Then,what is total of marbles of two by 20 minus?"(awkward numbers)

$S_{34}$ : "My father is 36 years old. My father is 8 times of my age. Then, what is the value of total age of us?"(inconsistent numbers)

S39: "My 19 teeth has grown in a week. Then, how many teeth will grow in three weeks?"(irrelevant to real life)

\section{Semi-Structured Problem Posing (according to operations SSPP-O)}

$5 \times 6=30$

$30-4=26$

Pose a problem such that its solution is as the above.

Looking at the results, the most difficult type of problem for students because of generating problem without attention to respectively two operations was seen easily. Students only pose a problem according to second operation or posed problem was not entirely appropriate for given situation. For this reason, the teacher wanted her students to follow operations that same as it is the solution of their posed problem. Another difficulty in problem posing activity was that students could not generate according to multiplication. A student posed a problem is "I have 5 candies and my mother gave me 6 times of mine. Then, my sister took 4 candies from me. How many candies I have?".

These results are in line with English's study in 1998. I was stated that “...grade 3 children were found to be inflexible in their problem creation, experiencing considerable difficulty in recognizing formal symbolism as representing a range of problem situations".

Some examples of this sessions are in the following:

$S_{3}$ : "Nurdan bought 5 apples. Erol bought 5 times more than Nurdan. Later, Nurdan bought 30 more of apples. If Nurdan eats 4 apples, how many apples remain?"

S9: "My mother is 6 set of 5 years old. My brother is four years younger than my mum. How old is my brother?"

$\mathrm{S}_{12}$ : "We had 5 curtains. We bought 6 times of them. 4 of curtains was closed, then how many curtains do we have?"

S33: "Our apartment has 5 floors and 6 people live on each floor. Ayse lives on the second floor. If Ayse's sister leaves home, then how many people do remain in Ayse's home?"

Also English (1997) studied to develop fifth grade students' problem posing ability. The researcher emphasized that students can not interpret operations adequately at the school. They should be provided to think deeply on meaning of operations. Hence, they can generate a new problem according to given operation.

\section{Semi-Structured Problem Posing (According to Figure, SSPP-F)}



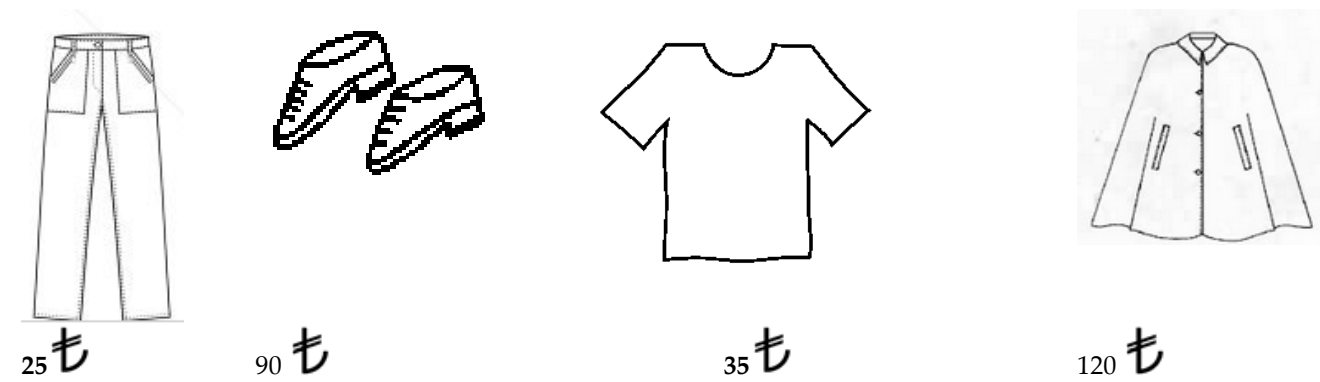

Figure 1. The prices of the things

Pose a problem by using the information in figure 1.

Because of this typeof problem stated in 3rd grade mathematics text book, sessions had no considerable difficulty. These sessions were consolidated with homework.

S39: "My mother has 30 liras. She bought a trouser, a shirt and a coat. How much Money does she have after the shopping?"

Table 1. Semi-Structured Problem Posing (According to Table)

\begin{tabular}{|c|c|}
\hline Fruits & Kilogram price (c) \\
\hline Strawberry & \\
\hline Pear & $50 \mathrm{Kr}$ \\
\hline Banana & \\
\hline Peach & ${ }_{4} 乇_{25 \mathrm{Kr}}$ \\
\hline Apricot & ${ }_{4}$ $_{75 \mathrm{Kr}}$ \\
\hline
\end{tabular}

Pose a problem by using the information according to the table 1.

Same as SSPP-F was in third grade mathematics text book/ students fell into error about currency and kilograms. An example of a student's problem was 'I bought $2 \mathrm{~kg}$ of bananas and $3 \mathrm{~kg}$ of strawberries. What is the sum of the two'. This question was not sufficiently clear. For this reason, the teacher gave the students homework for 2 times and made the students go to the blackboard. But students were much more successful in SSPP-F and SSPP-Tthanin SSPP-O.

S18: "I have 59 . I bought $2 \mathrm{~kg}$ bananas, $8 \mathrm{~kg}$ apricots and $12 \mathrm{~kg}$ pears. How much money remains back?"

S40: "I have 10 . Provided that I bought $1 \mathrm{~kg}$ banana, $1 \mathrm{~kg}$ strawberry and $1 \mathrm{~kg}$ apricot, then how much Money have remained back?"

\section{Results of pre-test and post-test}

In the non-experimental study, students were asked adding new information without changing the data given or conditions before and after the problem posing program.

Students made tiny distinctions in the expression and paid attention for constraint. The teacher guide for the students to add a new event or a person without changing the problem. Therefore, students' success rate increased from $\% 40$ to $\% 85$.

Table2. Frequency of Pre-test and Post-test 


\begin{tabular}{lll}
\hline Score & PRE-TEST & POST-TEST \\
\hline $\mathbf{0}$ & 9 & 2 \\
$\mathbf{1}$ & 1 & 0 \\
$\mathbf{3}$ & 14 & 4 \\
$\mathbf{5}$ & 16 & 34 \\
\hline
\end{tabular}

The number of student who had full score in pre-test is 16, in post-test is 34 .

Table 3. Non-Parametric Wilcoxon Sign Test Problem Posing 1 - Problem Posing 2

$\begin{array}{ll}\text { Z } & -3,926(\mathrm{a}) \\ \text { Asymp. Sig. (2-tailed) } & , 000\end{array}$

The Wilcoxon Signed-Rank Test was used for paired samples non-parametric test with $\propto=0,05$. Because of asymp sig $=0,00<0,05$, there is significant difference between PP pre-test and post-test on behalf of post-test.

Table4. Difficulty and limitedness

\begin{tabular}{|c|c|c|c|c|c|c|c|c|}
\hline & \multicolumn{4}{|l|}{ PRE-TEST } & \multicolumn{4}{|c|}{ POST-TEST } \\
\hline & $\begin{array}{l}\text { Writing a } \\
\text { sentence } \\
\text { question }\end{array}$ & Logic error & $\begin{array}{l}\text { Not suitable } \\
\text { for given }\end{array}$ & $\begin{array}{l}\text { Non } \\
\text { response }\end{array}$ & $\begin{array}{l}\text { Writing a } \\
\text { sentence } \\
\text { of } \\
\text { question }\end{array}$ & $\begin{array}{l}\text { Logic } \\
\text { error }\end{array}$ & $\begin{array}{l}\text { Not suitable } \\
\text { for given }\end{array}$ & $\begin{array}{l}\text { Non } \\
\text { respons } \\
\text { e }\end{array}$ \\
\hline$\hat{\omega}$ & $\mathrm{S}_{5}, \mathrm{~S}_{18}, \mathrm{~S}_{32,} \mathrm{~S}_{40}$ & $\begin{array}{l}S_{1}, S_{3}, S_{6}, S_{15}, \\
S_{17}, S_{19}, S_{20}, S_{21}, \\
S_{24}, S_{26}, S_{29}, S_{30}, \\
S_{31}, S_{32}, S_{36}, S_{37}\end{array}$ & $\mathrm{~S}_{39}$ & $\mathrm{~S}_{13}, \mathrm{~S}_{14}, \mathrm{~S}_{38}$ & - & $\begin{array}{l}S_{1}, S_{18}, S_{21}, \\
S_{24}\end{array}$ & - & $\mathrm{S}_{38}$ \\
\hline
\end{tabular}

Students were coded by turns and difficulties and limitedness which were faced by pupils were showed in Table 4.

\section{Examples of the Students}

S1 Pre-test: Erol has read 187 pages of his book. Nurdan has read less than 28 pages of Erol's. Ali has read 67 pages. How many pages have Erol, Nurdan and Ali read?"

S17 Pre-test: "Erol and Nurdan has read 187 pages of book together. Erol has read 20 more pages. The rest of book was read by Nurdan. How many pages have Nurdan and Erol read together?"

S20 Pre-test: "Yalcin has read 186 pages, while Nurdan has read 26 pages. How many pages have they read together?"

\section{Result of metaphor analyzing}

Just after all problem posing sessions these students used metaphor to indicate their personal insight about problem posing. Due to small number of students, their metaphors were identified by positive or negative conceptual categories.

Table 5. Frequency and Percent Distribution of Metaphors According to Gender

\begin{tabular}{lllll}
\multicolumn{3}{c}{ Positive } & Negative \\
\hline Gender & Frequency & Percent & Frequency & Percent \\
\hline
\end{tabular}




\begin{tabular}{lllll}
\hline Male & 17 & $\% 77,27$ & 5 & $\% 22,73$ \\
Female & 13 & $\% 72,22$ & 5 & $\% 27,78$ \\
\hline
\end{tabular}

Table 6. Frequency and Percent Distribution of Metaphors According to Score Interval

\begin{tabular}{lllll} 
& Positive & Negative \\
\hline Score & Frequency & Percent & Frequency & Percent \\
Not full Marks & 1 & $\% 25$ & 3 & $\% 75$ \\
Full Marks & 29 & $\% 80,56$ & 7 & $\% 19,44$ \\
\hline
\end{tabular}

Negative Metaphor Examples

"Problem posing is like driving. Because I have never driven a car. I do not know how to drive it"

"Problem posing is like launder. Because I cannot wash the clothes"

"Problem posing is like bottle. Because I cannot open bottle cap"

Looking at first example, this student implied that "If someone helps me, I can try to generate a problem". In others, they hinted that "I have real prejudice and nobody can shatter it". These metaphors are an important clue forthe teacher.

\section{Positive Metaphor Examples}

"Problem posing is like Shoestring. Because I can easily tie it"

"Problem posing is like brush teeth. Because it is simple and fun"

"Problem posing is like play the game. Because I play with numbers during problem posing"

Table7. Structured Interview with the Class Teacher

\begin{tabular}{|c|c|}
\hline $\begin{array}{l}\text { Which type of problem posing is suitable for the readiness } \\
\text { level of your students? }\end{array}$ & $\begin{array}{l}\text { They reflected their imagination by blending their numerical } \\
\text { experience with grammar rules in free type. We always use } \\
\text { auxiliary source for problem solving. This is a factor for their } \\
\text { success. Therefore, free problem posing is more suitable } \\
\text { formy students. }\end{array}$ \\
\hline $\begin{array}{l}\text { The students did not go forward according to operations in } \\
\text { semi-structured problem posing as expected. What could be } \\
\text { the reason for this? }\end{array}$ & $\begin{array}{l}\text { The students feel relax and free in free type and structured } \\
\text { type. In structured type they changed direction of the } \\
\text { problem whatever way they want. But there are many } \\
\text { constraints in semi-structured types. The students especially } \\
\text { did not show an achievement to generate a problem } \\
\text { according to operations because of multiplication. } \\
\text { Multiplication is abstraction. They use addition and } \\
\text { subtraction in real life but not multiplication. Multiplication } \\
\text { may be taught on the collection process as long as numbers } \\
\text { are small. In the opposite case, they cannot calculate on the } \\
\text { collection process. Hence they act by rote. Moreover, we had } \\
\text { never performed problem posing which is consisting of two } \\
\text { operations until then. }\end{array}$ \\
\hline Was there any changes for the students after the study? & $\begin{array}{l}\text { They enjoyed it. They have given me generating problems as } \\
\text { homework. We wrote a generating problem on board by a } \\
\text { student. The others made interpretation like that "Teacher!, } \\
\text { she did not add a new data", :Teacher!, this is good problem", } \\
\text { "Teacher! This problem cannot be solved". Afterwards, we } \\
\text { chose to write a problem which is the best on board. In my } \\
\text { opinion, they learned peer assessment and self evaluation. }\end{array}$ \\
\hline $\begin{array}{l}\text { Do you think problem posing can be used as an assessment } \\
\text { tool? }\end{array}$ & $\begin{array}{l}\text { I have decided to give wide coverage to problem posing } \\
\text { compared to the curriculum. Because I have thought } \\
\text { mathematics as a questioner. When a person who knows to } \\
\text { read and write can put something on paper his or her own } \\
\text { story. Suchlike, if a student grows in mature at mathematics } \\
\text { sufficiently, he or she can produce a question properly. But } \\
\text { individual's learning rate is not the same. Therefore, problem } \\
\text { posing can not be used for the general but the individual } \\
\text { according to me. }\end{array}$ \\
\hline
\end{tabular}

\section{Conclusion and Discussion}


Providing that students are bolstered to create or reformulate a problem, we can obtain their perceptions of problems and mathematical thinking. This can be thought as a pathfinder to future educational life. In Turkey, from 2006, problem posing has been a part of the Turkish curriculum which was reorganized in accordance with world standards. But it is suspicious that problem posing is implemented properly all around the Turkey (Arikan\&Unal, 2013). With this regard, problem posing activity should be existed into the mathematics teacher training program to prepare and assist prospective teachers to implement this activity properly. Also, a teacher should pose his/her problems that facilitate his/her students to grasp mathematical concepts and improve their mathematical thinking (Azima, Pillay and Adler, 2008).

This paper hold a discussion about problem posing types according to 3rd grade students' cognitive domain. The comparative analysis of pre-test and post-test showed that spending time on problem posing activity effects students' logical thinking and logical reasoning ability. In the study, it is identified by looking at Table3 that students'verbal ability were enriched. While 4 students who tried to write a problem were not successful in writing sentence of question of pre-test, all of students who response were successful in post-test. With respect to logical error, 16 students made logic error in pre-tests, but 4 students were in post-test. In order to make logical reasoning between concepts, problem posing is very useful technique (Kuretetski, 1976). To exemplify, the class teacher can see that $S_{1}, S_{21}$ and $S_{24}$ fell into error in logical reasoning. These students may nothave faced with the problems sufficiently or used mathematics in their life. The class teacher can decide to alternative teaching strategy for them.

English (1998) carried out a study which was related to third grade students. The participants were different profiles of succeed in number sense and novel problem solving. They were categorized as strong number sense/ strong problem solving, strong number sense/weak problem solving, weak number sense/strong problem solving. While childeren of SP/SN category displayed structural and operational complexity in their problems, WN/SP students only displayed structural complexity and SN/WP students only displayed operational complexity at the end of problem posing program.Many students tended to pose a problem which are directly modelled and solved. It was stated that the students were limited to generate a new problem.In each category, students performed better than before and generated multistep problem. This result is line with the result of our study in semistructured study.These students were expected to generate a problem according to operations, especially multiplication. This task allowed the teachertouseproblem posing as an assessment tool (Lin, 2004). Hence, the teacher obtains information about whether or not the students have misconceptions.Although the participants showed the remarkable success structured type problem posing, students did not go forward according to operations in semi-structured problem posing as expected. Also, it is said that the students are more successful on problem posing activities related to table when it is compared with figurative problem posing activities. The potential main reason might bethe fact that the students wereconfusedwith "times" and "times more" concepts. When students solved their own created problems, they did not recognize the difference between "times" and "times more" expressions. According to teacher, the reason of why the students did not success as expected is multiplication which is abstract concept.

In the structured problem posing, students were given a problem and asked to add a new data. When compared to pre-test and post-test by using Wilcoxon Sign Test, statistically significant difference $(\propto<0.05)$ in support of post-test.In the present case, using semi-structured problem posing activity nourishes structured problem posing ability. Similar situation was claimed by Abu-Elwan that "posing problems from a semi-structured situations" strategy is an effective strategy in developing problem posing skills...". The study of Abu-Elwan, there was two experimental groups and a control group to determine a strategy to improve the problem posing ability. One experimental group used textbook to pose a problem and the other one used semi-structured type to pose a problem. According to the 
result, semi-structured type was identified as an effective strategy to develop problem posing skill (Abu-Elwan, 1999).

For giving a proposal, the same tests can be repeated more than twice periodically. Also, students should be motivated for problem posing according to operations. In pre-test and post-test, the students may be asked separately metaphorical thoughts about problem posing and examined the difference. The students may generate a problem for friends by identifying conditions and constraints of problem. Therefore, they evaluate each other as a peer assessment. Likewise, the teacher not only see problem posing as an activity in lesson, but also use it as an assessment tool.

Problem posing activity nurtures the critical and creative thinking. When students mingle with problem posing tasks during learning process for mathematics lesson, they are able to make reasoning for their responses. For this reason, students will return to examiner (questioner) individuals in terms of what they do. As a matter of fact industrialized countries would like to examiner (questioner) individuals to grow up both for improving conditions in their countries and for competing the other countries in international area.

In the end of the study, students were asked to create a metaphor on problem posing. Students produced $75 \%$ positive and $25 \%$ negative metaphors. Total score of each of $S_{13}, S_{18}, S_{33}$, and S38is under the 15 points. While $S_{18}$ used positive metaphor for identifying problem posing, the others produced negative metaphors. Class teacher said in Table 6 that the three students could be evaluated individually. Furthermore, metaphor can be used as a research tool for understanding one's insight on a certain concept (Saban, 2009).

In the traditional education, the teachers ignore the individual differences of students. As already known, every student has different capabilities.Although, problem posing is important component of our mathematics curriculum, it is a question whether problem posing is inserted to our mathematics curriculum in terms of constructive approach. Besides, problem posing activity should be added in prospective mathematics teachers programs to let them to pose their problems. Hence, when they will become a teacher, they can help their students to generate a problem and think diversely.

Arikan and Unal (2014) remarked at their study that some teachers find their students incapable to solve a problem. For this reason, they prefer not to pose a problem instead of solving a problem. This issue should be noticed and a study can be carried out for future.

Problem posing is not perceived such that it can only be used for school mathematics. We can imagine an economist or an accountant. If she/he is confronted by a problem situation, she/he must solve it and be prepared for different forms of the problem. Namely, conditions of the problem can be changed in time. Therefore, problem posing is also effective practice for real life problems.

\section{References}

Abu-Elwan, R. (1999). The development of mathematical problem posing skills for prospective middle school teachers. In A. Rogerson (Ed.) Proceedings of the International conference on Mathematical Education into the 21st Century: Social Challenges, Issues and Approaches, (Vol. II, pp. 1-8), Cairo Egypt

Akay, H., Soybas ,D., Argun Z., (2006). Problem Posing Experiences and Using Open-Ended Questions in Mathematics Teaching. Kastamonu University Journal of Education. 14(1), 129-146.

Arikan, E. E.\&Unal, H. (2013). The Analysis of Mathematical Problem Posing Skill of Elementary Second Grade Students. Amasya Educational Journal. 2(2), 305-325.

Baxter, J. A. (2005). Some reflections on problem posing: A conversation with Marion Walter. Teaching Children Mathematics, 12(3), 122-128.

Bonotto, C., 2010. Engaging students in mathematical modeling and problem posing activities. J. Math. Model. App., 1(3): 1832.

Brown, S., I., \& Walter, M., .I. (1993). Problem Posing: Reflection and Application. Hilsdele, NJ: Erlbaum Associates. 
Brown, S. I., \& Walter, M. I. (2005). The art of problem posing. Mahwah, NJ: Lawrence Erlbaum Associates.

Buerk, D. (1982). An experience with some able women who avoid mathematics. For the Learning of Mathematics, 3(2), 19-24.

Cai, J., \& Hwang, S. (2002). Generalized and generative thinking in US and Chinese students' mathematical problem solving and problem posing. Journal of Mathematical Behavior, 21, 401-421

Duncker, K. (1945). On problem-solving. Psychological Monographs, 58(5).

Einstein, A., \& Infeld, L. (1938). The evolution of physics. New York: Simon \& Schuster.

El Sayed, R. A. E. (2002). Effectiveness of problem Posing Strategies on Prospective Mathematics Teachers' Problem Solving Performance. Journal of science and mathematics education in Southeast Asia, 25(1), 56-69.

English, L. D. (1997). The Development of Fifth-Grade Children's Problem-Posing Abilities. Educational Studies in Mathematics, 34(3), 183-217.

English, L. D. (1998). Children's problem posing within formal and informal contexts',Journal for

Research in Mathematics Education, 29(1), 83-106.

Georgiev, V., Nedyalkova, V., (2011). Group Creativity and Development of Mathematical Problem Posing And Solving Capabilities.The Seventh Congress of the European Society for Research in Mathematics Education CERME7, Poland.

Harpen, X. Y. V. \& Presmeg, N. C. (2013). An investigation of relationships between students' mathematical problem-posing abilities and their mathematical content knowledge. Educational Studies in Mathematics.83(1), 117-132.

Hlalele, D. (2012). Exploring rural high school learners' experience of mathematics

Anxiety in academic settings. South African Journal of Education.32(3), 267-278.

Hunt, C. (2006). Travels with a turtle: metaphors and the making of a Professional identity. Reflective Practice, 7(3), 315-332.

Kazima, M., Pillay, V.\&Adler, J. (2008). Mathematics for Teaching: Observations from Two Case Studies. South African Journal of Education.28 (12), 283-299.

Knowles, J. G. (1994). Metaphors as windows on a personal history: A beginning teacher's experience. Teacher Education Quarterly, 21(1), 37-66.

Krutetskii, V., A., (1976), the Psychology of Mathematical Abilities in School Children, University of Chicago Press, ISBN 0-22645492-4. Translated from the Russian by Joan Teller; edited by Jeremy Kilpatrick and Izaak Wirszup.

Lakoff, G., Johnson, M.,. (1980). Metaphors we live by. Chicago: University of Chicago.

Lakoff, G. (1992). "The Contemporary Theory of Metaphor", Ortony, A. (editor), Metaphor and Thought, Cambridge University Press

Lavy, I., Shriki, A., (2007). Problem posingas a Means for Developing Mathematical knowledge Of Prospective Teachers. Proceedings of the 31st Conference of the International Group for the Psychology of Mathematics Education, 3, 129-136.

Leung, S., S., (1993). The influence of task formats, mathematics knowledge, and creative thinking. Paper presented at the the 17th International Conference of the International Group for the Psychology of Mathematics Education, Tsukuba, Japan.

Lin, P., (2004). Supporting Teachers on Designing Problem-Posing Tasks asa Tool of Assessment to Understand Students' Mathematical Learning. Proceedings of the 28th Conference of the International Group for the Psychology of Mathematics Education, 3, 257-264.

Meintjes, H.\&Grosser, H. (2010).Creative thinking in prospective teachers: the 'Status quo' and the impact of contextual factors. South African Journal of Education. 30(3), 361-386.

Mestre, P., J., (2002). Probing adults' conceptual understanding and transfer of learning via problem posing, Applied Developmental Psychology, 23, 9-50.

NCTM(2000). Principals and Standards for School Mathematics, Reston, VA: National Council of Teachers of Mathematics Pub.

Pelczer, I. and F.G. Rodriguez, 2010. Creativity assessment in school settings through problem posing tasks. Mont. Math. Ent., 8(1-2): 383-398.

Saban, A. (2009). Öğretmen Adaylarının Öğrenci Kavramına İlişkin Sahip Oldukları Zihinsel İmgeler, Türk Eğitim Bilimleri Dergisi, 7(2), 281-326.

Silver, E., A., (1994). On mathematical problem posing. For the Learning of Mathematics, 14(1), 19-28.

Silver, E., A., \& Cai, J. (1996). An analysis of arithmetic problem posing by middle school students. Journal for Research in Mathematics Education, 521-539.

Silver, E., A., Mamona-Downs, J., Leung, S., S., \& Kenney, P., A., (1996). Posing mathematical problems: An exploratory study. Journal for Research in Mathematics Education, 27(3), 293-309.

Singer, F., M.; Ellerton, N.; Cai, J.; (2013). Problem-posing research in mathematics education: new questions and directions. . EducationStudiesinMathematics.1-7, DOI: 10.1007/s10649-013-9478-2.

Stoyanova, E., \& Ellerton, N., F., (1996). A framework for research into student's problem posing in school mathematics. Technology in mathematics education. Mel bourne: Mathematics Education Research Group of Australia.

Whitin, D., J., (2004). Building a mathematical community through problem posing. In R. N. P. Rubenstein \& G. W. Bright (Eds.), Perspectives on the teaching of mathematics: Sixty-sixth yearbook (pp. 129-140). Reston, VA: National Council of Teachers of Mathematics.

Yob, I. M. (2003). Thinking constructively with metaphors. Studies in Philosophyand Education, 22, 127-138. 